\title{
MODEL DAN STRATEGI MANAJEMEN LEMBAGA PENDIDIKAN ISLAM
}

\author{
Asep Muljawan ${ }^{1}$ \\ asepmulyawan2014@gmail.com
}

\begin{abstract}
Islamic education institutions must be able to build a strong Muslim generation, to master science and technology and noble character. To achieve this goal, Islamic education must be managed optimally through Islamic education institutions. This paper attempts to examine the factors that are successful in Islamic education institutions. This study focused on the management of Islamic education institusions to face challenges of globalization.

And this research is a quantitative research type of literature study. The results of the

literature review show that in managing quality LPI requires a management model, namely the LPI management model with nuance of entrepreneurship, community-based and mosque-based LPI management models. In addition, quality LPI requires management strategies both in general and specifically. Specifically known as strategic management.
\end{abstract}

Keyword: Model, strategic management, Islamic Education Institutions.

Abstrak
Lembaga Pendidikan Islam harus mampu membangun generasi Muslim yang tangguh,
menguasai ilmu pengetahuan dan teknologi dan berkarakter mulia. Untuk mencapai
tujuan tersebut maka pendidikan Islam harus dikelola secara maksimal melalui Lembaga
Pendidikan Islam. Tulisan ini berusaha mengkaji faktor-faktor keberhasilan Lembaga
Pendidikan Islam. Kajian ini difokuskan pada manajemen lembaga pendidikan Islam untuk
menghadapi tantangan globalisasi. Dan penelitian ini merupakan penelitian kualitatif
jenis studi pustaka. Hasil kajian pustaka menunjukkan bahwa dalam pengelolaan
Lembaga Pendidikan Islam bermutu memerlukan model manajemen yaitu model
manajemen LPI Bernuansa Entrepreneurship, model manajemen LPI Berbasis masyarakat
dan model manajemen LPI berbasis masjid. Selain itu, LPI bermutu memerlukan strategi
manajemen baik secara umum maupun khusus. Secara khusus dikenal dengan istilah
manajemen stratejik.

Kata Kunci : Model, Strategi Manajemen, Lembaga Pendidikan Islam.

\footnotetext{
${ }^{1}$ Dosen tetap prodi Pendidikan Agama Islam STAI Asy-Syukriyyah Tangerang
} 


\section{Pendahuluan}

Pendidikan merupakan masalah penting bagi kehidupan manusia, membantu manusia menuju ke arah pertumbuhan dan perkembangan. Tersurat dalam Undang-Undang Republik Indonesia Nomor 20 Tahun 2003 tentang Sistem Nasional Pendidikan, bahwa "Pendidikan merupakan usaha sadar dan terencana untuk mewujudkan suasana belajar dan proses pembelajaran agar peserta didik secara aktif mengembangkan potensi dirinya untuk memiliki kekuatan spiritual keagamaan, pengendalian diri, kepribadian, kecerdasan, akhlak mulia, serta keterampilan yang diperlukan dirinya, masyarakat, bangsa dan negara". ${ }^{2}$

Pendidikan merupakan ujung tombak dalam mempersiapkan generasi yang handal, karena pendidikan akan dapat memaksimalkan potensi peserta didik. Melalui pendidikan potensi siswa akan terus digali sedemikian rupa guna menjadi insan yang handal untuk dapat bersikap kritis, logis, dan inovatif dalam menghadapi dan menyelesaikan setiap permasalahan yang dihadapinya.

Peranan Lembaga Pendidikan dalam mewujudkan tujuan Pendidikan tersebut menjadi sangat penting. Saat ini Lembaga Pendidikan bermutu menjadi perhatian utama banyak orang baik secara individu maupun dalam suatu organisasi. Mereka menganggap bahwa Lembaga pendidikan yang berkualitas akan banyak dibutuhkan dan karena nya memiliki peluang untuk memenangkan kompetisi ditengah-tengah kehidupan masyarakat yang semakin maju.

Demikian pula sebuah Lembaga Pendidikan Islam harus bermutu untuk menjaga eksistensinya dan bertahan ditengah kompetisi yang sangat ketat sekarang ini. Jadi mutu merupakan hal yang wajib dan harus ada dalam lembaga Pendidikan. ${ }^{3}$ Agar mutu pendidikan tersebut dapat dicapai maka lembaga pendidikan harus mampu

\footnotetext{
${ }^{2}$ Undang-Undang RI No 20 Tahun 2003 Tentang Sistem Nasional Pendidikan.

${ }^{3}$ Arcaro, J. (2007). Pendidikan Berbasis Mutu: Prinsip-prinsip perumusan dan Tata Langkah Penerapan (Terj. Yosai Triantara). Yogyakarta: Pustaka Belajar.
} 


\section{Jurnal Asy-Syukriyyah}

mengoptimalkan fungsi dan peran seluruh sumber-sumber daya pendidikan baik sumber daya manusia maupun sarana dan prasarana fisik lainnya yang dimiliki. ${ }^{4}$

Secara fungsional, pendidikan pada dasarnya ditujukan untuk menyiapkan manusia menghadapi masa depan agar hidup lebih sejahtera, baik sebagai individu maupun secara kolektif sebagai warga masyarakat, bangsa maupun antar bangsa. Bagi pemeluk agama, masa depan mencakup kehidupan di dunia dan pandangan tentang kehidupan hari kemudian yang bahagia. ${ }^{5}$ Sementara itu, visi pendidikan Islam adalah melahirkan manusia sholeh dalam ilmu, amal dan akhlaknya. Sedangkan misi yang ingin dicapai adalah pertama, mendidik dan mengajarkan ajaran Islam secara kaffah (komprehenshif) sehingga peserta didik mengetahui dan memahami sekaligus memiliki keasadaran yang tinggi untuk mengamalkannya. Kedua, memberikan bekal agar para siswa mampu berpartisipasi dan berkontribusi seberapapun besar kecilnya dalam kehidupan sosial. serta memiliki kemampuan berkompetisi dengan tetap berpijak pada rambu-rambu ajaran Islam. Menurut Abuddin Nata, Cita-cita besar yang ingin dicapai melalui Pendidikan Islam adalah menjadikan ajaran Islam sebagai landasan yang kuat dan membumi dalam segala sendi kehidupan. $^{6}$

Namun saat ini dunia pendidikan kita belum sepenuhnya dapat memenuhi harapan masyarakat. Fenomena itu ditandai dari rendahnya mutu lulusan, penyelesaian masalah pendidikan yang tidak sampai tuntas, atau cenderung tambal sulam, bahkan lebih berorintasi proyek. Akibatnya, seringkali hasil pendidikan mengecewakan masyarakat. Mereka terus mempertanyakan relevansi pendidikan dengan kebutuhan masyarakat dalam dinamika kehidupan ekonomi, politik, sosial, dan budaya. Kualitas lulusan pendidikan kurang sesuai dengan kebutuhan pasar tenaga kerja dan pembangunan, baik industri, perbankan, telekomunikasi, maupun pasar tenaga kerja sektor lainnya yang cenderung

\footnotetext{
${ }^{4}$ Chotimah,C \& Fathurrohman,M. (2014). Komplemen Manajemen Pendidikan Islam: Konsep Integratif Pelengkap Manajemen Pendidikan Islam. Yogyakarta: Teras.

${ }^{5}$ Umaedi. (2017). Manajemen Mutu Berbasis Sekolah/Madrasah. Komunikasi dan Pendidikan Islam, Vol 6 No 2,1 .

${ }^{6}$ Nata, A. (2010). Ilmu Pendidikan Islam. Jakarta: Kencana Prenada.
} 
menggugat eksistensi sekolah. Bahkan SDM yang disiapkan melalui pendidikan sebagai generasi penerus belum sepenuhnya memuaskan bila dilihat dari segi akhlak, moral, dan jati diri bangsa dalam kemajemukan budaya bangsa.

Pendidikan Islam juga dihadapkan dan terperangkap pada persoalan yang sama, bahkan apabila diamati maka pendidikan Islam terkukung dalam kemunduran, keterbelakangan, ketidakberdayaan, dan kemiskinan, sebagaimana pula yang dialami oleh sebagian besar negara dan masyarakat Islam dibandingkan dengan mereka yang non Islam. Katakan saja, pendidikan Islam terjebak dalam lingkaran yang tak kunjung selesai yaitu persoalan tuntutan kualitas, relevansi dengan kebutuhan, perubahan zaman, dan bahkan pendidikan apabila diberi “embel-embel Islam”, dianggap berkonotasi kemunduran dan keterbelakangan, meskipun sekarang secara berangsur-angsur banyak diantara lembaga pendidikan Islam yang telah menunjukkan kemajuan. ${ }^{7}$

Hal ini, merupakan suatu kenyataan yang selama ini dihadapi oleh lembaga pendidikan Islam di Indonesia. Olah karena itu, muncul tuntutan masyarakat sebagai pengguna pendidikan Islam agar ada upaya penataan dan modernisasi sistem dan proses pendidikan Islam agar menjadi pendidikan yang bermutu, relevan, dan mampu menjawab perubahan untuk meningkatkan kualitas manusia Indonesia. Berbagai upaya untuk membangun sekolah/madrasah bermutu yang berintegritas tinggi, berkemajuan, berkeunggulan, berdaya saing serta mampu menghasilkan lulusan sebagai generasi yang banyak memberi manfaat bagi sesama dimanapun ia berada, telah-sedang dan terus dilakukan.

\footnotetext{
${ }^{7}$ Soeroyo, I. (1991). Berbagai Persoalan Pendidikan, Pendidikan Nasional dan Pendidikan Islam di Indonesia. Jurnal Ilmu Pendidikan Islam, Problem dan Prospeknya. Vol. I, FAk. Tarbiyah IAIN Yogyakarta, h.77.
} 


\section{Jurnal Asy-Syukriyyah}

Berdasarkan penelitian terdahulu, telah dilakukan beberapa penelitian dalam pengelolaan lembaga pendidikan dalam rangka pencapaian tujuan pendidikan dan strategi peningkatan mutu Pendidikan. ${ }^{8}$

Berdasarkan penelitian yang telah dilakukan sebelumnya, keterbaruan dalam penelitian ini terletak pada bagaimana Model dan Strategi Manajemen Lembaga Pendidikan Islam dalam menghadapi tantangannya.

\section{Metode Penelitian}

Jenis penelitian yang digunakan adalah model penelitian kualitatif dengan studi pustaka, yaitu kajian teoritis, referensi serta literatur ilmiah lainnya yang berkaitan dengan budaya, nilai dan norma yang berkembang pada situasi sosial yang diteliti. ${ }^{9}$ Penelitian kualitatif bertujuan memperoleh gambaran seutuhnya mengenai suatu hal menurut pandangan manusia yang diteliti. Penelitian kualitatif berhubungan dengan ide, persepsi, pendapat, atau kepercayaan orang yang diteliti; kesemuanya tidak dapat diukur dengan angka.

\section{Hasil Penelitian dan Pembahasan}

\section{Lembaga Pendidikan Islam dan Tantangannya}

Lembaga pendidikan merupakan hal yang sangat penting dalam mencapai keberhasilan proses pendidikan karena lembaga berfungsi sebagai mediator dalam mengatur jalannya pendidikan. Dan pada zaman sekarang ini tampaknya tidaklah disebut pendidikan jika tidak ada lembaganya. Lembaga pendidikan dewasa ini juga sangat mutlak keberadaannya bagi kelancaran proses pendidikan. Apalagi lembaga pendidikan itu dikaitkan dengan konsep islam. Lembaga pendidikan islam merupakan suatu wadah

\footnotetext{
${ }^{8}$ Ardimen. (2012), Fathurrohman, M. (2012), Himayaturohmah, E. (2017),Khadijah, I. (2015), Khojir. (2011), Priyatna, (2016), Rohman, F. (2016), Rozi, M. (2016), Riyuzen. (2017), Sodiah. (2016), Sulistyorini. (2012), TAnu, I. (2016).

${ }^{9}$ Sugiyono. (2012). Statistika Untuk Penelitian. Bandung : Alfabeta.
} 
dimana pendidikan dalam ruang lingkup keislaman melaksanakan tugasnya demi tercapainya cita-cita umat islam.

Kata "lembaga" menurut Kamus Besar Bahasa Indonesia berarti badan atau organisasi yang tujuannya melakukan suatu penyelidikan keilmuan atau melakukan usaha. ${ }^{10}$ Sedangkan yang dimaksud pendidikan Islam adalah "sebagai proses mengubah tingkah laku individu dalam kehidupan pribadinya atau kehidupan kemasyarakatannya dan alam sekitarnya melalui interaksi yang dilakukan oleh individu tersebut." ${ }^{11}$ Jadi, yang dimaksud dengan lembaga pendidikan Islam adalah lembaga atau badan, tempat berlangsungnya proses pendidikan yang dilakukan dengan tujuan untuk mengubah tingkah laku individu ke arah yang lebih baik melalui interaksi dengan lingkungan sekitarnya. Perubahan dimaksud tentunya dilandasi oleh nilai-nilai islami. ${ }^{12}$

Dengan demikian dapat dikatakan bahwa Lembaga Pendidikan Islam (LPI) merupakan suatu Lembaga/wadah/media/organisasi tempat dimana pendidikan Islam diselenggarakan. Lembaga ini memiliki struktur organisasi dan pembagian tugas/wewenang dan tanggung jawab yang jelas, tertata dengan baik sehingga memungkinkan terciptanya suasana kondusif yang mendukung terlaksananya proses pendidikan dan pembelajaran Agama Islam dengan efektif sesuai dengan karakteristik dan tugas masing-masing, seperti sekolah/madrasah.

Tujuan lembaga pendidikan Islam maka tidak terlepas dari tujuan pendidikan Islam itu sendiri. Tujuan pendidikan Islam digali dari nilai-nilai ajaran Islam yang bersumber dari al-Qur'an dan Hadits. Lembaga pendidikan Islam secara umum bertujuan untuk meningkatkan keimanan, pemahaman, penghayatan dan pengalaman peserta didik tentang agama Islam, sehingga menjadi manusia muslim yang beriman dan bertakwa kepada Allah SWT serta berakhlak mulia dalam kehidupan pribadi, bermasyarakat berbangsa dan

\footnotetext{
${ }^{10}$ Tim Penyusun. (1999). KAmus Besar Bahasa Indonesia. Jakarta : Balai Pustaka.

${ }^{11}$ Al-Syaibany, O.M. (1979). Falsafah Pendidikan Islam, alih Bahasa: Hasan Langgulung. Jakarta: Bulan Bintang.

${ }^{12}$ Suharto, M.T. (2005). Rekonstruksi dan Modernisasi Lembaga Pendidikan. Yogyakarta: Global Utama Pustaka.
} 


\section{Jurnal Asy-Syukriyyah}

bernegara. ${ }^{13}$ Dengan kata lain, lembaga pendidikan Islam mempunyai tujuan untuk mengembangkan semua potensi yang dimiliki manusia itu, mulai dari tahapan kognisi, yakni pengetahuan dan pemahaman siswa terhadap ajaran Islam, berikut dilanjutkan dengan tahapan afeksi, yakni terjadinya proses internalisasi ajaran dan nilai agama ke dalam diri siswa, dalam arti menghayati dan meyakininya. Melalui tahapan efeksi tersebut diharapkan bertumbuh motivasi dalam diri siswa untuk bergerak mengamalkan dan menaati ajaran Islam (tahap psikomotorik) yang telah diinternalisasikan dalam dirinya. Dengan demikian, akan terbentuk manusia muslim yang bertakwa dan berakhlak mulia.

Lembaga pendidikan Islam seperti halnya sekolah/madrasah umumnya adalah merupakan lembaga pendidikan kedua setelah keluarga. Menurut An-Nahlawi, "Tugastugas yang ditambah oleh Lembaga pendidikan Islam adalah: 1) merealisasikan pendidikan Islam yang didasarkan atas prinsip pikir, aqidah dan tasyri' (sejarah) yang diarahkan untuk mencapai tujuan pendidikan. Bentuk dan realisasi itu adalah agar anak didik beribadah, mentauhidkan Allah SWT, tunduk dan patuh kepada perintah dan syariat-Nya. 2) Memelihara fitrah anak didik sebagai insan yang mulia, agar tidak menyimpang dari tujuan Allah menciptakannya. 3) Memberikan kepada anak didik seperangkat peradaban dan kebudayaan Islami dengan cara mengintengrasikan antara ilmu-ilmu alam, ilmu sosial, ilmu eksak, dengan landasan ilmu-ilmu agama, sehingga anak didik mampu melibatkan dirinya terhadap perkembangan ilmu pengetahuan dan teknologi. 4) Membersihkan pikiran dan jiwa anak didik dari pengaruh subyektivitas (emosi) karena pengaruh zaman yang terjadi pada dewasa ini lebih mengarahkan pada penyimpangan fitrah manusia. 5) Memberikan wawasan nilai dan moral, dan peradaban manusia yang membawa khasanah pemikiran anak didik menjadi berkembang. 6.) Menciptakan suasana kesatuan dan kesamaan antara anak didik. 7) tugas mengkoordinasi dan membebani kegiatan

\footnotetext{
${ }^{13}$ Muhamin, \& Mujib, A. (1993). Pemikiran Pendidikan Islam. Bandung : Trigenda Karya.
} 
pendidikan. 8) Menyempurnakan tugas-tugas lembaga pendidikan keluarga, masjid dan pesantren". 14

Tugas lembaga pendidikan pada intinya adalah sebagai wadah untuk memberikan pengarahan, bimbingan dan pelatihan agar manusia dengan segala potensi yang dimilikinya dan dapat dikembangkan dengan sebaik-baiknya. Tugas lembaga pendidikan Islam yang terpenting adalah dapat mengantarkan manusia kepada misi penciptaannya sebagai hamba Allah, sebagai kholifah fi Al-Ardhi, yaitu seorang hamba yang mampu beribadah dengan baik dan dapat mengembangkan amanah untuk menjaga dan untuk mengelolah serta melestarikan bumi dengan mewujudkan kebahagiaan dan kesejahteraan seluruh alam.

Dalam perkembangannya Lembaga Pendidikan Islam banyak mengalami tantangan, salah satunya adalah globalisasi. Kata ini diartikan sebagai suatu proses meningkatnya keterkaitan antara masyarakat sehingga satu peristiwa yang terjadi di wilayah tertentu semakin lama akan kian berpengaruh terhadap manusia dan masyarakat yang hidup di bagian lain di muka bumi ini, dengan kata lain globalisasi sebagai sebuah proses sosial yang ditandai dengan semakin intensifnya hubungan sosial yang mengglobal. Artinya, kehidupan manusia di suatu wilayah akan berpengaruh kepada kehidupan manusia di wilayah lain, dan begitu sebaliknya. Selanjutnya Era globalisasi ditandai dengan beberapa hal, yaitu: pertama, globalisasi terkait erat dengan kemajuan dan inovasi teknologi, arus informasi atas komunikasi yang lintas batas negara. Kedua, globalisasi tidak dapat dilepaskan dari akumulasi kapital, semakin tingginya intensitas arus investasi, keuangan dan perdagangan global. Ketiga, globalisasi berkaitan dengan semakin tingginya intensitas perpindahan manusia, pertukaran budaya, nilai dan ide yang lintas batas negara. Keempat,

\footnotetext{
${ }^{14}$ An-Nahlawi, A. (1989). Prinsip-prinsip dan Metode Pendidikan Islam Dalam Keluarga, Sekolah dan Masyarakat, Terj. Herry Noer Ali. Bandung: Diponegoro.
} 


\section{Jurnal Asy-Syukriyyah}

globalisasi ditandai dengan semakin meningkatnya tingkat keterkaitan dan ketergantungan tidak hanya antar bangsa namun juga antar masyarakat. ${ }^{15}$

Sementara Pendidikan islam memiliki karakteristik, yaitu: (1) Penguasaan ilmu pengetahuan, bahwa ajaran dasar Islam mewajibkan pemeluknya mencari ilmu pengetahuan, (2) Pengembangan ilmu pengetahuan, yaitu ilmu yang telah dikuasai harus diberikan dan dikembangkan kepada orang lain, (3) Penekanan pada nilai-nilai akhlak dalam penguasaan dan pengembangan ilmu pengetahuan, (4) Dasar beribadah kepada Allah dan kemaslahatan umat, (5) Memperhatikan perkembangan anak didik, (6) Pengembangan kepribadian Islam, dan (7) Penekanan pada amal saleh dan tanggung jawab sosial. $^{16}$

Satu sisi globalisasi memberikan tantangan kepada Pendidikan Islam yang memiliki karakteristik tersebut di atas, ketika sikap positif terhadap tantangan globalisasi ini maka tantangan ini menjadi peluang harapan eksistensi Pendidikan islam. Sikap positif ini diikuti dengan persiapan-persiapan adaptif bahkan antisipatif. Sikap tersebut merujuk kepada petunjuk-petunjuk agama yang antara lain: “...sesungguhnya Allah tidak akan mengubah hal-hal yang ada pada suatu umat, sehingga mereka melakukan perubahan atas dirinya sendiri...” (QS. Ar-Ra'du:11). Petunjuk lainnya, firman Allah swt; “Janganlah kamu mengikuti hal-hal yang kamu tidak mengetahuinya, sesungguhnya pendengaran, penglihatan, dan hati, masing-masingnya akan dimintai pertanggungjawabannya” (QS. Al-Isra: 36).

Kedua landasan ideal fundamental di atas cukup mengingatkan kepada kita bahwa manusia sebagai anggota masyarakat janganlah statis dan jumud dalam hidupnya, melainkan hendaknya dinamis dan konstruktif dalam melakukan perubahan-perubahan. Tingkah laku dan usaha perubahan yang dilakukan itu hendaknya jangan latah mengikuti ide orang lain yang tidak diketahui arah dan tujuannya. Semua usaha perubahan yang

\footnotetext{
${ }^{15}$ Mulkhan, A. M. (2004). Pendidikan Islam dan Tantangan Globalisasi, Buah Pikiran Seputar Filsafat, Politik, Ekonomi, Sosial dan Budaya. Yogyakarta : Presma UIN Yogyakarta.

${ }^{16}$ Mulkhan, A. M. (2004). Pendidikan Islam dan Tantangan Globalisasi, Buah Pikiran Seputar Filsafat, Politik, Ekonomi, Sosial dan Budaya. Yogyakarta : Presma UIN Yogyakarta.
} 
dilakukan itu harus dipertanggung jawabkan dihadapan Tuhan, apakah bermanfaat bagi manusia, masyarakat, dan agama. Itulah sebabnya semua usaha untuk menciptakan perubahan itu perlu dilandasi nilai-nilai yang tetap dan yang konstruktif, yaitu nilai agama.

Tantangan lainnya adalah popularitas Lembaga Pendidikan (sekolah umum) makin meningkat. Sedangkan Lembaga Pendidikan Islam (sekolah Islam) bagi sebagian masyarakat kita dianggap sekolah cadangan ( alternatif bila tidak diterima di sekolah umum). Argumen klasiknya adalah bahwa sekolah umum dianggap lebih mampu bersaing dalam menyiapkan lulusan yang berkualitas dibandingkan dengan sekolah Islam atau sekolah berwawasan Islam. Meskipun akhir-akhir ini mulai muncul sekolah Islam atau pun sekolah umum berwawasan Islam yang mampu menunjukkan prestasinya, namun jumlahnya masih relatif sedikit (Harahap, 1998).

\section{Model Manajemen Lembaga Pendidikan Islam}

Berdasarkan sejarahnya, Lembaga Pendidikan Islam khususnya pesantren dan madrasah itu tumbuh dari bawah; dari gagasan tokoh-tokoh agama setempat. Berawal dari pengajian-pengajian di rumah kemudian mendirikan mushalla/masjid, madrasah diniyah, bahkan mendirikan pesantren dan madrasah. Sebagian besar tumbuh dan berkembang dari kecil dan kondisinya serba terbatas. Dalam perkembangannya diantara Lembaga Pendidikan Islam tersebut ada yang terus tumbuh dan berkembang dengan pesat atau mengalami continuous quality improvement, ada juga yang jalan di tempat dan ada pula yang berguguran. Bagi lembaga pendidikan islam yang terus berkembang umumnya didukung oleh usaha-usaha lain yang bersifat profit seperti pertanian, perdagangan, percetakan, industri jasa dan lain sebagainya.

Sejak pengaruh era globalisasi, kesadaran umat untuk meningkatkan mutu lembaga pendidikan Islam mulai bangkit dimana-mana dan beberapa di antaranya telah mampu menjadi sekolah unggul atau sekolah yang efektif (effective school). Yang menjadi persoalan adalah model manajemen yang bagaimana yang tepat bagi Lembaga pendidikan 


\section{Jurnal Asy-Syukriyyah}

Islam yang memiliki mutu tinggi dan berkarakter islami. Adapun model-modelnya yaitu sebagai berikut:

a. Model Manajemen LPI Bernuansa Entrepreneurship

Model ini merupakan pola manajemen LPI yang dapat memberikan nilai tambah. Winarto dalam Syafrudin menegaskan bahwa seorang entrepreneur adalah seorang yang menyukai perubahan, melakukan berbagai temuan yang membedakan dirinya dengan orang lain, menciptakan nilai tambah, memberikan manfaat bagi dirinya dan orang lain, karyanya dibangun berkelanjutan (bukan ledakan sesaat) dan dilembagakan agar kelak dapat bekerja dengan efektif di tangan orang lain. Seorang manajer LPI yang entrepreneur memiliki karakter sebagai berikut: berani mengambil resiko, menyukai tantangan, hambatan dan bahkan ancaman, punya daya tahan yang tinggi, punya visi jauh ke depan dan selalu berusaha memberikan yang terbaik. ${ }^{17}$

Seorang entrepreneur pada dasarnya adalah seorang pembaharu (innovator) karena melakukan sesuatu yang baru, dianggap baru atau berbeda dari kondisi sebelumnya. Apa yang dilakukan itu membawa perubahan ke arah yang lebih baik dan memberi nilai tambah bagi diri maupun orang lain. Dalam upaya untuk menciptakan nilai tambah seorang entrepreneur sangat mengutamakan kekuatan brand, yaitu citra atau merek yang kuat atas apa yang dilakukannya. Dengan brand yang baik jelas akan memberikan value yang tinggi. Brand image bagi sebuah lembaga pendidikan merupakan aset yang paling berharga yang mampu menciptakan value bagi stakeholder dengan meningkatkan kepuasan dan menghargai kualitas dan akhirnya melahirkan kepercayaan. Seorang manajer yang sekaligus entrepreneur bukan sekedar bisa membangun brand belaka, namun juga memanfaatkan kekuatan brand untuk melipatgandakan akselerasi sebuah perubahan. Berikut kalimat singkat, menarik yang diucapkan oleh KH Ahmad Dahlan, "Hidup-hidupi Muhammadiyah dan jangan mencari hidup di Muhammadiyah". Dapat ditafsirkan dalam konteks semangat

\footnotetext{
${ }^{17}$ Syafaruddin, (2005). Manajemen Lembaga Pendidikan Islam. Jakarta : Ciputata Press.
} 
entrepreneurship. Artinya setiap orang yang bekerja di lembaga amal usaha Muhammadiyah harus mampu memberikan nilai tambah bagi perkembangan lembaganya. Dengan cara inilah akan terjadi penumpukan capital (capital development) sehingga amal usaha Muhammadiyah dapat terus tumbuh dan berkembang.

b. Model Manajemen LPI Berbasis Masyarakat

Model ini merupakan pola manajemen LPI yang dapat menjaga hubungan baik dengan masyarakat sekitar. Berdasarkan "Data EMIS Kementerian Agama menunjukkan $90 \%$ madrasah berstatus swasta dan $100 \%$ pesantren adalah swasta". Ini berarti bahwa lembaga pendidikan Islam adalah lembaga milik masyarakat, atau bisa dikatakan "dari, oleh dan untuk masyarakat". Konsep Manajemen LPI berbasis sekolah (Management Based School) dan pendidikan berbasis masyarakat (Society Based Education) dalam konteks otonomi daerah, lahir karena dilandasi oleh kesadaran bahwa masyarakat punya peran dan tanggung jawab terhadap lembaga pendidikan di daerahya disamping sekolah dan pemerintah.

Lembaga-lembaga pendidikan di negara-negara maju terutama yang berstatus privat pada umumnya terdapat lembaga semacam Dewan Sekolah, Majlis Madrasah, Dewan Penyantun, Majlis Wali Amanah dan lain sebagainya yang antara lain bertugas memperhatikan hubungan, kedekatan dan aspirasi masyarakat serta siap mendayagunakan potensi masyarakat dan memberikan layanan pengabdian (langsung maupun tidak langsung) kepada masyarakat. Di Stanford University misalnya ada The Board of Trustees yang berwenang mengelola dana hibah dan hadiah (grand), sumbangan (endowment) dan lain sebagainya yang dihimpun dari dana masyarakat untuk pengembangan Stanford University. ${ }^{18}$

Semangat beramal untuk membangun lembaga pendidikan dalam tradisi iman umat Islam sebenarnya bukan sesuatu yang baru, bahkan umat Islam pernah menjadi

${ }^{18}$ Syafaruddin, (2005). Manajemen Lembaga Pendidikan Islam. Jakarta : Ciputata Press. 


\section{Jurnal Asy-Syukriyyah}

pelopor (avant-garde) dalam komitmennya mengembangkan lembaga pendidikan melalui semangat amal. Yang menjadi persoalan sekarang adalah, bagaimana upaya rekonstruksi semangat beramal ini dalam mengembangkan pendidikan Islam? Pertama, adanya lembaga semacam Board of Trustees atau semacam Majlis Wali Amanah yang anggotanya dari wakil masyarakat yang memiliki integritas dan komitmen yang tinggi terhadap pendidikan Islam. Kedua, perlu dibangkitkan kembali semangat juang (jihad), etos kerja semua komponen stake holder internal sebagai wujud amal (perbuatan) nyata. Ketiga, perlu diterapkan manajemen mutu terpadu (total quality management) dalam penyelenggaraan pendidikan Islam. ${ }^{19}$

\section{c. Model Manajemen LPI Berbasis Masjid}

Embrio pendidikan Islam adalah Masjid. Manajemen Lembaga pendidikan Islam yang berbasis masjid adalah manajemen yang dijiwai oleh nilai dan semangat spiritual, semangat berjamaah, semangat ikhlas (murni karena Allah) dan semangat memberi yang hanya berharap pada ridlo Allah. Proses pembelajaran yang integratif dengan masjid memberikan nuansa religius yang kental dalam penanaman nilai-nilai religius maupun praktek langsung pengalaman beragama. Mengapa berbasis masjid?

Menurut Muhbib Abdul Wahab yang dimuat pada harian Republika Online (ROL) bahwa "Masjid adalah pusat dan sumber inspirasi dalam segala hal, karena di masjid semua Muslim hanya mengabdi dan memohon pertolongan kepada Allah SWT (QS Al-Fatihah [1]: 5). Ayat ini oleh para mufassir, antara lain, dimaknai ayat pembebasan manusia dari ketergantungan kepada makhluk menuju tauhid sejati. Shalat berjamaah di masjid tidak hanya melambangkan persatuan dan kebersamaan, tetapi juga persamaan (equality), egalitarianisme, dan anti-diskriminasi. Yang kaya dan miskin, pejabat dan rakyat, penguasa dan pengusaha dapat berdiri dalam shaf yang sama. Tidak ada masjid hanya dikhususkan para penguasa, pengusaha, atau pejabat. Masjid,

\footnotetext{
${ }^{19}$ Syafaruddin, (2005). Manajemen Lembaga Pendidikan Islam. Jakarta : Ciputata Press.
} 
seperti halnya kemerdekaan, adalah hak semua. Masjid mendidik kita untuk mandiri, mengembangkan semangat kebersamaan, nasionalisme, dan patriotisme sejati”. ${ }^{20}$

Berdasarkan deskripsi model-model di atas, maka dapat disintesakan bahwa Lembaga Pendidikan Islam (LPI) dapat memadukan ketiga model manajemen tersebut karena ketiga model tersebut bersesuaian secara filosofis, teoritis dan empirik.

\section{Strategi Manajemen Lembaga Pendidikan Islam (LPI)}

Ada beberapa strategi alternatif untuk menjawab berbagai tantangan manajemen (pengelolaan) LPI, yaitu strategi Umum dan strategi khusus (Qomar, 2007). Strategi umum meliputi; (1) Merumuskan cita-cita, program , dan tujuan serta langkah-langkah realisasi, (2) Membangun kepemimpinan, budaya organisasi yang baik dan profesional serta menyiapkan pendidik yang memiliki kompetensi, (3) Menggali potensi-potensi keuangan dan mengembangkannya dengan kreatif, (4) Membangun kerjasama (networking) baik ditingkat daerah, nasional maupun internasional, (5) Sikap optimis, peduli, aktif dan kreatif dalam menghadapi berbagai tantangan.

Strategi Umum lainnya, yaitu; (1) strategi substantive; sekolah-sekolah Islam seperti madrasah, pondok pesantren dan LPI lainnya perlu menyajikan program-program yang komprehensif meliputi aspek Kognitif (pemahaman), afektif (penerimaan atau sikap) dan psikomotorik (pengalaman atau keterampilan), (2) strategi bottom-up; Pertumbuhan dan perkembangan LPI harus dimulai dari bawah. Artinya konsep dan rancang bangun kurikulum serta berbagai kebijakan pengembangan kualitas SDM dan sarana fisik lainnya harus disesuaikan dengan kebutuhan, potensi dan cita-cita masyarakat. Masyarakat harus dilibatkan sejak dari tahap perencanaan, pelaksanaan sampai pada tahap evaluasi. Konsep kebersamaan yang dibangun dari bawah inilah yang diyakini mampu menumbuhkan sikap kepedulian yang tinggi (concern), rasa memiliki (sense of belonging), dan rasa turut bertanggung jawab (sense of responsibility) atas prestasi yang dicapai. Keikutsertaan masyarakat ini dapat saja direfresentasikan oleh Komite Sekolah/Madrasah. Organisasi ini

\footnotetext{
${ }^{20}$ Wahab, M. A. (2013). Spirit Istiqlal, diposting pada 22 Agustus 2013, diakses pada 24 Juli 2019. Jakarta: http://khazanah.republika.co.id/berita/dunia-islam/hikmah/13/08/22/mrwy9w-spirit-istiqlal.
} 
perlu bekerja sama bahu membahu guna memajukan kualitas sekolah. (3) strategi deregulatory; Sekolah-sekolah Islam/madrasah dan LPI lainnya seharusnya diberi kebebasan untuk berkreasi dan berimprovisasi terhadap programprogram pembinaan dan pengembangan, tidak terlalu terpaku dan kaku pada aturan umum yang di buat oleh pemerintah. (4) strategi cooperative; Dalam proses pembinaan dan pengembangannya, maka sekolah/madrasah dan LPI lainnya harus bisa bekerja sama, (berkolaborasi) dan memberdayakan semua potensi dan sumber daya yang ada baik dari internal maupun dari lingkungan sekitarnya ${ }^{21}$

Adapun strategi khusus dalam menghadapi tantangan pengelolaan LPI yaitu pendekatan manajemen stratejik; suatu seni dan ilmu dari pembuatan (formulating), penerapan (implementing), dan evaluasi (evaluating) keputusan-keputusan strategis antar fungsi-fungsi yang memungkinkan sebuah organisasi mencapai tujuan-tujuan masa yang akan datang. ${ }^{22}$ Manajemen stratejik dapat pula didefinisikan sebagai proses perencanaan, pengarahan, pengorganisasian dan pengendalian berbagai keputusan dan tindakan strategis sekolah dengan tujuan untuk mencapai keunggulan kompetitif. ${ }^{23}$

Proses manajemen strategik terdapat 3 tahap ${ }^{24}$, yaitu:

(1) Perencanaan Strategi, yang meliputi :

a. Pengembangan Visi, Misi dan Tujuan

b. Pengidentifikasian faktor internal dan eksternal (analisis SWOT)

c. Perencanaan jangka pendek, menengah, dan Panjang

d. Penentuan strategi unggul.

(2) Pelaksanaan Strategi, yaitu meliputi:
a. Menentukan Kebijakan Sekolah
b. Memotivasi karyawan
c. Mengalokasikan sumber-sumber daya manusia

${ }^{21}$ Sirozi, M. (2004). Agenda Strategi Pendidikan Islam. Yogyakarta: AK Group.

${ }^{22}$ Nawawi, H. (2005). Manajemen Stratejik Organisasi Non Profit Bidang Pemerintahan dengan Ilustrasi di Bidang Pendidikan. Yogyakarta: Gajah Mada University Press.

${ }^{23}$ Solihin, I. (2012). Manajemen Stratejik. Bandung : Erlangga.

${ }^{24}$ Solihin, I. (2012). Manajemen Stratejik. Bandung : Erlangga. 
d. Mengembangkan budaya yang mendukung strategi

(3) Evaluasi/kontrol strategi, mencakup:

a. Memonitor seluruh hasil-hasil dari pembuatan dan penerapan strategi

b. Mengukur Kinerja Individu dan Sekolah

c. Mengambil Langkah-langkah perbaikan

Berdasarkan deskripsi di atas, manajemen stratejik diwujudkan dalam bentuk perencanaan berskala besar, dalam arti mencakup kepentingan seluruh komponen organisasi. Hasil rumusan rencana ini biasanya dituangkan dalam bentuk rencana-rencana organisasi secara hierarkis, yakni: rencana strategis (renstra), rencana operasional (renop), program, dan kegiatan. Rencana strategik ini berorientasi ke masa depan (misal 10 tahun ke atas). Visi dan misi organisasi menjadi acuan dalam penyusunan rencana strategis. Diperlukan keterlibatan pimpinan puncak dalam penyusunan rencana strategis, dan Hasil rumusan rencana strategis diimplementasikan melalui fungsi manajemen.

\section{Penutup}

Berdasarkan uraian di atas, dapat disimpulkan bahwa Lembaga Pendidikan Islam (LPI) Sebagai wadah pembelajaran Pendidikan Islam harus dikelola secara efektif dan efisien dengan tetap berpijak pada ajaran Islam, sehingga peran LPI signifikan dalam membangun pribadi-pribadi dengan kemampuan intelektual yang mumpuni, karakter keimanan yang tangguh, serta akhlak mulia. Dengan kepribadian tersebut maka mereka mampu menghadapi tantangan global.

Dalam merespon tantangan era globalisasi ini, Lembaga pendidikan Islam seharusnya tetap memberikan respon positif dan solutif tanpa mengurung diri, tetap inklusif dengan tanpa meninggalkan karakter dan basic yang dimilikinya. Lembaga Pendidikan Islam memang perlu melakukan penggabungan berbagai model manajemen dan menerapkan strategi manajemen baik secara umum maupun secara khusus yang dikenal dengan istilah manajemen stratejik (management strategic). 


\section{DAFTAR PUSTAKA}

al Syaibany, O. M. (1979). Falsafah Pendidikan Islam, alih bahasa Hasan Langgulung. Jakarta: Bukan Bintang.

An-Nahlawi, A. (1989). Prinsip-prinsip dan Metode Pendidikan Islam dalam Keluarga, Sekolah dan Masyarakat, Terj. Herry Noer Ali. Bandung: Diponegoro.

Arcaro, J. (2007). Pendidikan Berbasis Mutu: Prinsip-prinsip Perumusan dan Tata Langkah Penerapan (Terj. Yosai Triantara). Yokyakarta: Pustaka Belajar.

Ardimen. (2012). Pengelolaan Lembaga Pendidikan Berbasis SNP Dalam Rangka Pencapaian Tujuan Pendidikan. Jurnal Ta'dib, 15 (2), 137-148.

Chotimah, C., \& Fathurrohman, M. (2014). Komplemen Manajemen Pendidikan Islam: Konsep Integratif Pelengkap Manajemen Pendidikan Islam. Yogyakarta: Teras.

Fathurrohman, M. (2012). Implementasi Manajemen Peningkatan Mutu Pendidikan Islam: Peningkatan Lembaga Pendidikan Islam Secara Holistik (Praktik dan Teoritik). Yogyakarta: Teras.

Harahap, S. (1998). Perguruan Tinggi Islam di Era Globalisasi. Yogyakarta: Tiara Wacana.

Himayaturohmah, E. (2017). Strategi Pengembangan Manajemen Pengelolaan Pusat Kegiatan Belajar MAsyarakat (Pkbm) Di Provinsi Riau. Jurnal Penjamin Mutu, 3 (1), 100-110.

Khadijah, I. (2015). Manajemen Mutu Terpadu (TQM) Pada Lembaga Pendidikan Islam. Al-Idarah: Jurnal Kependidikan Islam, 5(1), 59-75.

Khojir. (2011). Pengebangan Lembaga Pendidikan di Indonesia. Jurnal Dinamika Ilmu, 11 (2), 1-9. 
Muhaimin, \& Mujib, A. . (1993). Pemikiran Pendidikan Islam. Bandung: Trigenda Karya.

Mulkhan, A. M. (2004). Pendidikan Islam dan Tantangan Globalisasi , Buah Pikiran Seputar Filsafat, Politik,Ekonomi, Sosial dan Budaya. Yogyakarta: Presma UIN Yogyakarta.

Nata, A. (2010). Ilmu Pendidikan Islam . Jakarta: Kencana Prenada.

Nawawi, H. (2005). Manajemen strategik Organisasi Non Pofit Bidang Pemerintahan dengan Ilustrasi di Bidang Pendidikan. Yogyakarta: Gajah Mada University Press.

Priyatna. (2016). Manajemen Pengembangan SDM Pada Lembaga Pendidikan Islam. Edukasi Islami Jurnal Pendidikan Islam, 1231-1250.

Qomar, M. (2007). Manajemen Pendidikan Islam. Malang: Erlangga.

Riyuzen. (2017). Strategi Pengelolaan Lembaga Pendidikan Islam. Al-Tadzkiyyah: Jurnal Pendidikan Islam, 8 (2), 145-165.

Rohman, F. (2014). Strategi Pengelolaan Komponen Pembelajaran Bahasa Arab. Arabiyat: JUrnal Pendidikan Bahasa Arab dan Kebahasaaraban, I (1), 64-78.

Rozi, M. (2016). Strategi PEningkatan Mutu Pendidikan Islam. Jurnal Edukasi, 4 (2), 322336.

Sirozi, M. (2004). Agenda Strategi Pendidikan Islam. Yogyakarta: AK Group.

Sisdiknas, U.-U. (2003). Sistem Nasional Pendidikan.

Sodiah. (2016). Manajemen Lembaga Pendidikan Islam Berbasis Masyarakat dan Sekolah. Jurnal Sosial Budaya, 89-100. 


\section{Jurnal Asy-Syukriyyah}

Soeroyo. (1991). Berbagai Persoalan Pendidikan, Pendidikan Nasional dan Pendidikan Islam di Indonesia. Jurnal Ilmu Pendidikan Islam, Problem dan Prospeknya. Vol I. Fak Tarbiyah IAIN Yogyakarta, 77.

Solihin, I. (2012). Manajemen Strategik. Bandung: Erlangga.

Sugiyono. (2012). Statistika untuk Penelitian. Bandung: Alfabeta.

Suharto, M. T. (2005). Rekonstruksi dan Modernisasi Lembaga Pendidikan . Yogyakarta: Global Utama Pustaka.

Sulistyorini, M. (2012). Implementasi Manajemen Peningkatan Mutu Pendidikan Islam: Yogyakarta: Teras.

Syafaruddin. (2005). Manajemen Lembaga Pendidikan Islam. Jakarta: Ciputat Press.

Tanu, I. (2016). Pembelajaran Berbasis Budaya dalam Meningkatkan Mutu Pendidikan di Sekolah. Jurnal Penjamin Mutu, 34-43.

Tim Penyusun. (1999). Kamus Besar Bahasa Indonesia. Jakarta: Balai Pustaka.

Umaedi. (2017). Manajemen Mutu Berbasik Sekolah/Madrasah. Komunikasi dan Pendidikan Islam, Vol 6 No 2, 1.

Wahab, M. A. (2013). Spirit Istiqlal, diposting pada 22 Agustus 2013, diakses pada 24 Juli 2019.Jakarta:http://khazanah.republika.co.id/berita/duniaislam/hikmah/13/08/22/mrwy9w-spirit-istiqlal. 